\title{
Ondansetron Hydrochloride in Treating Patients with Cancer and Chronic Nausea Vomiting
}

Hye jin *, Baek Km , Hyang Jihun, jinwoo

Department of Biotechnology, Korea.

*Corresponding Author : Hye jin, Department of Biotechnology, Korea. E-mail: hyejin@gmail.com

Received date: August 11,2017;Accepted date : August 30,2017; Published date: September 08,2017.

Citation for this Article: Hye jin, Baek Km , Hyang Jihun, jinwoo Ondansetron Hydrochloride in Treating Patients with Cancer and Chronic Nausea Vomiting, J Cancer Research and Cellular Therapeutics, Doi: 10.31579/2640-1053/012

Copyright : (c) 2017 Hye jin. This is an open-access article distributed under the terms of The Creative Commons Attribution License, which permits unrestricted use, distribution, and reproduction in any medium, provided the original author and source are credited.

\begin{abstract}
The objective of this study was to develop effective bioadhesive buccal bilayered tablets comprising of drug containing bioadhesive layer and drug free backing layer, expected to release the drug in unidirection for extended period of time. Tablets of ondansetron $\mathrm{HCl}$ were prepared by direct compression method using bioadhesive polymers like Carbopol 934P, Methocel K4M, Methocel K15M and Hydroxy propyl cellulose in different combinations and concentrations with backing layer of ethyl cellulose. Buccal tablets were evaluated by different parameters such as thickness, hardness, weight uniformity, content uniformity, swelling index, surface $\mathrm{pH}$, ex vivo bioadhesive strength, ex vivo residence time, in vitro drug release, ex vivo drug permeation, stability studies in human saliva, in vivo mucoadhesive performance studies and FTIR studies. The modified in vitro assembly was used to measure the bioadhesive strength of tablets with fresh porcine buccal mucosa as model tissue. Bioadhesion strength was increased with increase in the concentration of carbopol. The tablets were evaluated for in vitro release in pH 6.6 phosphate buffer for $8 \mathrm{hr}$ in standard dissolution apparatus. In order to improve the permeation of the drug, tauroglycholate (permeation enhancer) added in the optimized formulation at $10 \mathrm{mM}$ concentration. In order to determine the mode of release, the data was subjected to Korsmeyer and Peppas diffusion model. The optimized formula followed non-fickian release mechanism with zero order kinetics. Carbopol 934P and HPC in the ratio of 3:1 could be used to design effective and stable buccoadhesive tablets of ondansetron $\mathrm{HCl}$. The present study concludes that buccal delivery of ondansetron $\mathrm{HCl}$ tablets can be good way to bypass the first pass metabolism.
\end{abstract}

\section{Introduction}

The oral cavity is an attractive site for drug delivery due to ease of administration, avoidance of possible drug degradation in the gastrointestinal tract, and first-pass metabolism. Within the oral mucosal cavity, delivery of drugs is classified into three categories: (i) sublingual delivery, which is systemic delivery of drugs through the mucosal membranes lining the floor of the mouth (ii) buccal delivery, which is drug administration through the mucosal membranes lining the cheeks (buccal mucosa), and (iii) local delivery, which is drug delivery into the oral cavity.

The buccal region of the oral cavity is an attractive target for administration of the drug of choice. Buccal delivery involves the administration of the desired drug through the buccal mucosal membrane lining of the oral cavity. Unlike oral drug delivery, which presents a hostile environment for drugs, especially proteins and polypeptides, due to acid hydrolysis and the hepatic first-pass effect, the mucosal lining of buccal tissues provides a much milder environment for drug absorption. Other routes, such as nasal, ocular, pulmonary, rectal, and vaginal drug administration, have provided excellent opportunities for the delivery of a variety of compounds. However, the mucosal lining of the oral cavity offers some distinct advantages.

Mechanisms by which penetration enhancers are thought to improve mucosal absorption are as follows (Ganem et al., 1996; Siegel et al., 1985). Changing mucus rheology: Mucus forms viscoelastic layer of varying thickness that affects drug absorption. Further, saliva covering the mucus layers also hinders the absorption. Some Permeation enhancers act by reducing the viscosity of the mucus and saliva overcomes this barrier.
- Increasing the fluidity of lipid bilayer membrane: The most accepted mechanism of drug absorption through buccal mucosa is intracellular route. Some enhancers disturb the intracellular lipid packing by interaction with either lipid packing by interaction with either lipid or protein components.

- Acting on the components at tight junctions: Some enhancers act on desmosomes, a major component at the tight junctions there by increases drug absorption

- By overcoming the enzymatic barrier: These act by inhibiting the various peptidases and proteases present within buccal mucosa, thereby overcoming the enzymatic barrier. In addition, changes in membrane fluidity also alter the enzymatic activity indirectly.

Bioadhesive buccal delivery of drugs is one of alternative to the oral route of drug administration; particularly drugs that are undergoing first pass effect. Administering the drug via the buccal route can circumvent problems such as drug degradation in the harsh gastrointestinal environment, inconvenience of parenteral administration.

In particular, the buccal route appears to offer a series of advantages, such as good accessibility, robustness of the epithelium, facile removal of the dosage form in case of need, relatively low enzymatic activity, and possibility of elimination of the administered dosage from the buccal area by natural clearance mechanisms, satisfactory patient acceptance and compliance. 


\section{MATERIALS AND METHODS - METHODOLOGY}

\section{Table . List Of Materials}

\begin{tabular}{|l|l|l|}
\hline S.No. & \multicolumn{1}{|c|}{ Material } & \multicolumn{1}{c|}{ Manufacturer } \\
\hline 1 & $\begin{array}{l}\text { Ondansetron } \\
\text { hydrochloride }\end{array}$ & $\begin{array}{l}\text { Zydus Cadila, Ahmedabad, } \\
\text { India. }\end{array}$ \\
\hline 2 & Carbopol 934 P & $\begin{array}{l}\text { Zydus Cadila, Ahmedabad, } \\
\text { India. }\end{array}$ \\
\hline 3 & $\begin{array}{l}\text { Hydroxy propyl methyl } \\
\text { cellulose K15 M }\end{array}$ & $\begin{array}{l}\text { AET laboratories, Hyderabad, } \\
\text { India. }\end{array}$ \\
\hline 4 & $\begin{array}{l}\text { Hydroxy propyl methyl } \\
\text { cellulose K4M }\end{array}$ & $\begin{array}{l}\text { AET laboratories, Hyderabad, } \\
\text { India. }\end{array}$ \\
\hline 5 & $\begin{array}{l}\text { Hydroxy } \\
\text { cellulose }\end{array}$ & $\begin{array}{l}\text { AET laboratories, Hyderabad, } \\
\text { India. }\end{array}$ \\
\hline 6 & Ethyl cellulose & $\begin{array}{l}\text { Vilin Biomed Ltd, Roorkee, } \\
\text { India. }\end{array}$ \\
\hline 7 & Mannitol & $\begin{array}{l}\text { Vilin Biomed Ltd, Roorkee, } \\
\text { India. }\end{array}$ \\
\hline 8 & Spray dried lactose & $\begin{array}{l}\text { Dr Reddy's laboratories, } \\
\text { Hyderabad, India. }\end{array}$ \\
\hline 9 & $\begin{array}{l}\text { Microcrystalline } \\
\text { cellulose }\end{array}$ & $\begin{array}{l}\text { Viilin Biomed Ltd, Roorkee, } \\
\text { India. }\end{array}$ \\
\hline 10 & Sodium taurocholate & Moly Chem, Mumbai, India. \\
\hline 11 & Aspartame & $\begin{array}{l}\text { Dr Reddy's laboratories, } \\
\text { Hyderabad, India. }\end{array}$ \\
\hline 12 & Magnesium stearate & $\begin{array}{l}\text { Vilin Biomed Ltd, Roorkee, } \\
\text { India. }\end{array}$ \\
\hline
\end{tabular}

\section{Lisł Of Instruments}

\begin{tabular}{|c|c|c|}
\hline S.No. & Instrument & Make \\
\hline 1 & $\begin{array}{l}\text { Electronic Weighing } \\
\text { Balance }\end{array}$ & $\begin{array}{l}\text { A } \quad \text { W } 120, \\
\text { Corporation, Japan. }\end{array}$ \\
\hline 2 & $\begin{array}{l}\text { Tablet compression } \\
\text { machine }\end{array}$ & Cadmach, Ahmedabad, India. \\
\hline 3 & Dissolution & $\begin{array}{l}\text { Electro lab TDT- } 08 \mathrm{~L}, \\
\text { Mumbai, India. }\end{array}$ \\
\hline 4 & $\begin{array}{l}\text { UV/visible } \\
\text { Spectrophotometer }\end{array}$ & Systronics, Ahmedabad, India. \\
\hline 5 & Friability test apparatus & $\begin{array}{l}\text { INCO Instruments and } \\
\text { chemicals Pvt Ltd, Ambala } \\
\text { city, India. }\end{array}$ \\
\hline 6 & pH meter L I 120 & $\begin{array}{lll}\text { Elico India } & \text { Pvt } & \text { Ltd, } \\
\text { Hyderabad, India. } & & \\
\end{array}$ \\
\hline 7 & Magnetic stirrer & Remi, Mumbai, India. \\
\hline 8 & $\begin{array}{l}\text { Tablet disintegration } \\
\text { tester ED-2L }\end{array}$ & Electrolab, Mumbai, India. \\
\hline
\end{tabular}

Bilayered buccal tablets were prepared by a direct compression method, before going to direct compression all the ingredients were screened through sieve no.100, except lubricant all the ingredients were thoroughly blended in a glass mortar with pestle for $15 \mathrm{~min}$. After sufficient mixing lubricant was added and again mixed for additional 2-3 min. Preparation involves two steps, first the mixture is compressed using $8 \mathrm{~mm}$ flat faced punch on 16 stages rotary tablet compress machine. Then upper punch is raised and the backing layer of ethyl cellulose is placed on above compact then two layers are compressed again to get bilayered buccal tablet (Vishnu et al., 2007).

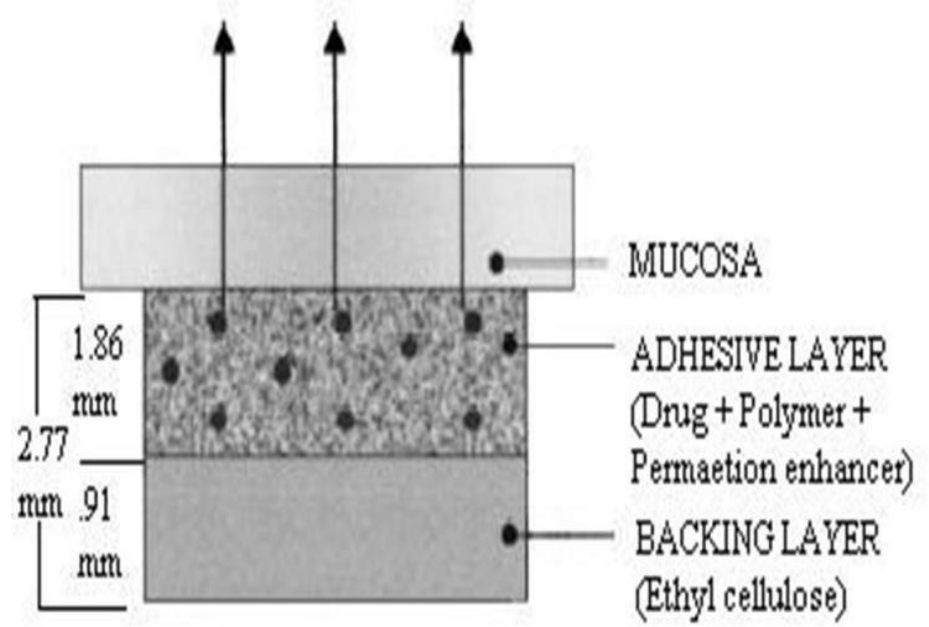

\section{Results And Discussions}

\section{Standard graph of ondansetron $\mathrm{HCl}$ :}

Table. Standard graph of ondansetron $\mathrm{HCl}$ in phosphate buffer $\mathrm{pH}$ 6.6

\begin{tabular}{|c|c|c|}
\hline S.No. & Concentration $(\mathbf{m c g} / \mathbf{m L})$ & Absorbance $(\mathbf{n m})$ \\
\hline 1 & 4 & 0.240 \\
\hline 2 & 8 & 0.377 \\
\hline 3 & 12 & 0.505 \\
\hline 4 & 16 & 0.656 \\
\hline 5 & 20 & 0.789 \\
\hline 6 & 24 & 0.945 \\
\hline
\end{tabular}

Table. Standard graph of ondansetron $\mathrm{HCl}$ in phosphate buffer $\mathrm{pH}$ 7.4

\begin{tabular}{|c||c|c|}
\hline S.No. & Concentration(mcg/mL) & Absorbance (nm) \\
\hline 1 & 4 & 0.198 \\
\hline 2 & 8 & 0.354 \\
\hline 3 & 12 & 0.487 \\
\hline 4 & 16 & 0.645 \\
\hline 5 & 20 & 0.796 \\
\hline 6 & 24 & 0.925 \\
\hline
\end{tabular}

Table . Standard graph of ondansetron $\mathrm{HCl}$ in methanol

\begin{tabular}{|c|c|c|}
\hline S.No. & $\begin{array}{c}\text { Concentration } \\
(\mathbf{m c g} / \mathbf{m L})\end{array}$ & Absorbance (nm) \\
\hline 1 & 4 & 0.164 \\
\hline 2 & 8 & 0.307 \\
\hline 3 & 12 & 0.473 \\
\hline 4 & 16 & 0.597 \\
\hline 5 & 20 & 0.726 \\
\hline 6 & 24 & 0.934 \\
\hline
\end{tabular}




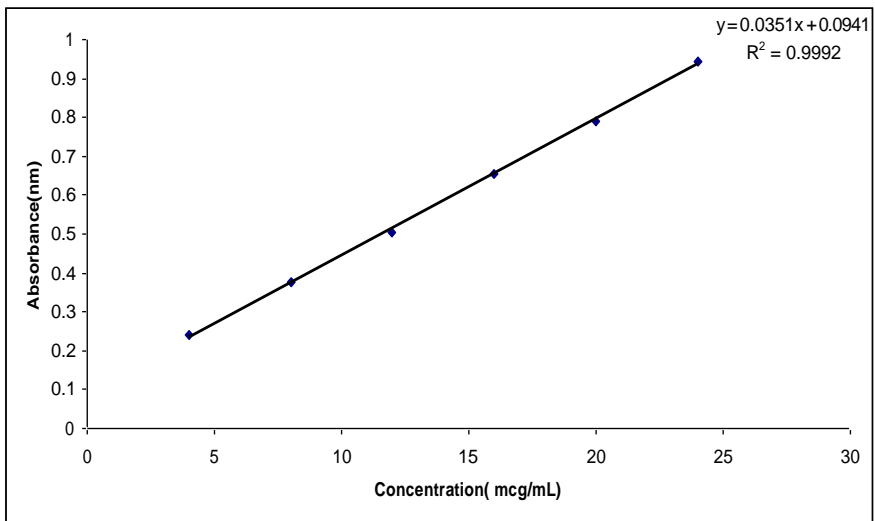

Standard graph of ondansetron $\mathrm{HCl}$ in phosphate buffer pH 6.6.

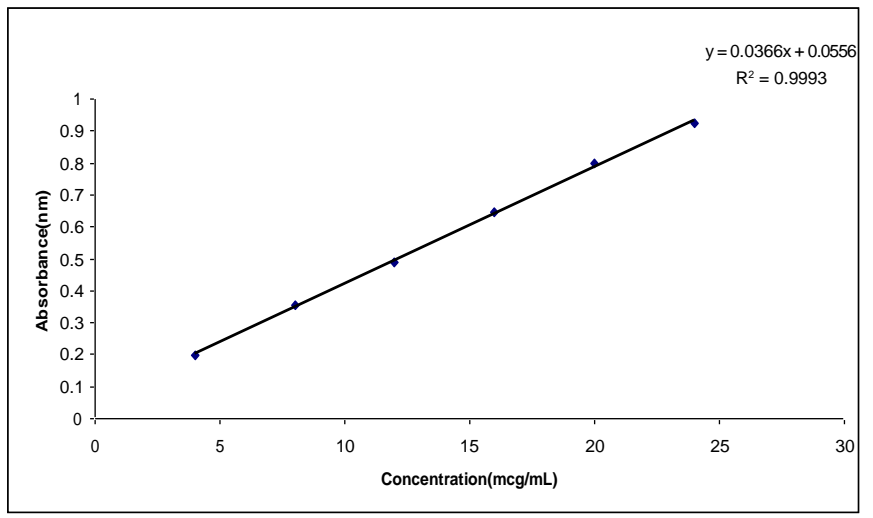

Standard graph of ondansetron $\mathrm{HCl}$ in phosphate buffer $\mathrm{pH}$ 7.4.

The solubility study was conducted in $\mathrm{pH} 6.6$ and $\mathrm{pH} 7.4$ phosphate buffers because these are average $\mathrm{pH}$ values of oral cavity and blood respectively. Solubility of ondansetron $\mathrm{HCl}$ in the $\mathrm{pH} 6.6$ and $\mathrm{pH} 7.4$ was found to be $10 \pm 2.85 \mathrm{mg} / \mathrm{mL}, 5.9 \pm 3.23 \mathrm{mg} / \mathrm{mL}$ respectively. The flux and permeability coefficient of drug solution was found to be $0.71408 \mathrm{mg} . \mathrm{hrs}^{-1} \mathrm{~cm}^{-2}$ and $0.08925 \mathrm{~cm} / \mathrm{h}$ respectively. The values of weight variation and friability were found to be within the limits of conventional oral tablets stated in the Indian Pharmacopoeia (IP, 1996). No tablet was disintegrated within $4 \mathrm{hr}$.Thickness of the tablets varied from $2.26 \mathrm{~mm}$ to $2.75 \mathrm{~mm}$ and complied with the theoretical value $(2.75 \mathrm{~mm})$. Hardness of the tablets was increased as the concentration of the carbopol increased and ranging from $3.8 \mathrm{Kg} / \mathrm{cm}^{2}$ to $7.7 \mathrm{Kg} / \mathrm{cm}^{2}$. The assay values were also within the limits $98.0 \%-102 \%$.

\section{Physico-chemical parameters of formulations}

Table 14. Physico-chemical parameters of formulations containing HPMC K15M/ HPMC K4M

\begin{tabular}{|c|c|c|c|c|c|}
\hline $\begin{array}{l}\text { Formulat } \\
\text { ion } \\
\text { code }\end{array}$ & $\begin{array}{l}\text { Thickness } \\
\text { (mm) }\end{array}$ & \begin{tabular}{|l} 
Weight \\
Variation(mg)
\end{tabular} & $\begin{array}{l}\text { Friab } \\
\text { ility } \\
(\%)\end{array}$ & $\begin{array}{l}\text { Hardness } \\
\left(\mathrm{Kg} / \mathrm{cm}^{2}\right)\end{array}$ & $\begin{array}{l}\text { \%Drug } \\
\text { content }\end{array}$ \\
\hline F1 & $2.43 \pm 0.010$ & $142.6 \pm 0.20$ & 0.09 & $4.3 \pm 0.13$ & 99.74 \\
\hline F2 & $2.26 \pm 0.020$ & $146 \pm 0.24$ & 0.17 & $4.8 \pm 0.33$ & 101.17 \\
\hline F3 & $2.73 \pm 0.035$ & $151.9 \pm 0.15$ & 0.08 & $5.3 \pm 0.13$ & 99.69 \\
\hline F4 & $2.64 \pm 0.010$ & $155.2 \pm 0.70$ & 0.07 & $6.6 \pm 0.10$ & 99.04 \\
\hline F5 & $2.64 \pm 0.040$ & $149 \pm 0.50$ & 0.24 & $4.6 \pm 0.10$ & 99.58 \\
\hline F6 & $2.71 \pm 0.030$ & $156.3 \pm 0.20$ & 0.31 & $5.1 \pm 0.05$ & 100.39 \\
\hline F7 & $2.70 \pm 0.010$ & $159.9 \pm 0.25$ & 0.42 & $5.5 \pm 0.05$ & 99.57 \\
\hline F8 & $2.64 \pm 0.030$ & $157.3 \pm 0.60$ & 0.08 & $6.7 \pm 0.05$ & 99.07 \\
\hline F9 & $2.71 \pm 0.042$ & $147.9 \pm 0.50$ & 0.08 & $3.9 \pm 0.09$ & 99.40 \\
\hline F10 & $2.38 \pm 0.057$ & $152.9 \pm 0.48$ & 0.42 & $4.9 \pm 0.15$ & 99.37 \\
\hline F11 & $2.56 \pm 0.023$ & $154.4 \pm 0.20$ & 0.08 & $4.7 \pm 0.21$ & 99.38 \\
\hline F12 & $2.55 \pm 0.010$ & $153.1 \pm 0.47$ & 0.46 & $5.6 \pm 0.10$ & 101.03 \\
\hline
\end{tabular}

Each value represents the mean $\pm \operatorname{SD}(n=3)$.

\section{Conclusion}

Development of bioadhesive buccal drug delivery of ondansetron $\mathrm{HCl}$ tablets is one of the alternative routes of administration to avoid first pass effect and provide prolongs release. A combination of carbopol 934 and hydroxyl propyl cellulose at the ratio of $3: 1$ is with complementary physical properties. From the results, it was concluded that the in vitro drug release, bioadhesion strength, ex vivo residence time of the optimized formulation is suitable for buccal delivery. The release pattern followed non-fickian diffusion with Zero order release. The results strongly suggest that increase in cumulative drug permeated was due to effect of tauroglycholate on paracellular and transcellular pathways. FTIR studies concluded that there was no interaction between drug and excipients. From healthy human volunteers it was revealed that all subjective parameters and mucoadhesion behavior were found to be satisfactory.

\section{References}

1. Affi EA, Mahmoud MS, E1-Samaligy NN. Increasing bioavailability of silymarin using a buccal liposomal delivery. Int $J$ Pharma. 2006;308:140-148.

2. Agarwal V, Mishra B. Design, development, and biopharmaceutical properties of buccoadhesive compacts of pentazocine. Drug Dev Ind Pharm. 1999;25:701-709.

3. Agarwal V, Mishra B. Design, development, and biopharmaceutical properties of buccoadhesive compacts of pentazocine. Drug Dev Ind Pharm. 1999;25:701-709.

4. Ahuja A, Dogra M, Agarwal SP. Development of buccal tablets of diltiazem hydrochloride. Indian J Pharm Sci. 1995;57:26- 30.

5. Ahuja A, Khar RK, Ali J. Mucoadhesive drug delivery systems. Drug Dev Ind Pharm. 1997;23(5) :489-517.

6. Ahuja A, Khar RK, Ali J. Mucoadhesive drug deliverysystems. Drug Dev Ind Pharm. 1997;23:489- 515.

7. Akbari J, Nokhodchi A, Farid D, Adrangui M, Siahi-Shadbad MR, Saeedi M. Development and evaluation of buccoadhesive propranolol hydrochloride tablet formulations: Effect of fillers, $I L$ Farmaco. 2004; 59:155- 161.

8. Allen A, in: J.G. Forte (Ed.), Handbook of Physiology - the Gastrointestinal Physiology, Salivary, Gastric and Hepatobiliary Secretions. American Physiological Society, Bethesda MD, 1989;3(6):359-382.

9. Allen C, Maysinger D, Eisenberg A. Nano-engineering block copolymer aggregates for drug delivery, Colloids Surf., B. Biointerfaces Spec. Issue, Polym Micelles Biol Pharma. 1999;16:327.

10. Alur HH, Pather SI, Mitra AK, Johnston TP. Transmucosal sustained delivery of chlorpheniramine maleate in rabbits using a novel natural mucoadhesive gum as an excipient in buccal tablets. Int J Pharm. 1999;188:1-10.

11. Amal Kumar Bandyopadhyay, Pulak Kumar Metia. In vitro evalution of novel mucoadhesive buccal tablets of oxytocine diospyros peregrina fruits mucilage. The pharmaceutical society japan. 2008;128: 603-609.

12. Anders R, Merkle HP. Evaluation of laminated muco-adhesive patches for buccal drug delivery. Int J Pharm. 1989;49:231-240.

13. Audus KL. Oral mucosal drug delivery, in: Rathbone MJ (Ed.), Marcel Dekker, New York, 101-119.

14. Aungst A. Permeability and metabolism as barriers to transmucosal delivery of peptides and proteins. in: Hsieh DS (Ed.) , Drug Permeation Enhancement.Theory and Applications, Marcel Dekker, New York, 1994: 323-343.

15. Barichello JM, Morishita M, Takayama K, Chiba Y, Tokiwa S, Nagai T. Enhanced rectal absorption of insulinloaded PluronicR F127 gels containing unsaturated fatty acids. Int $J$ Pharm. 1999; 183:125-132.

16. Batchelor H. Novel bioadhesive formulations in drug delivery, The Drug Delivery Companies Report Autumn/Winter. Pharma Ventures Ltd, 2004. 
17. Bottenberg P, Cleymaet R, Muynek CD, Remon JP, Coomans D, Slop D. Development and testing of bioadhesive, fluoridecontaining slow-release tablets for oral use. J Pharm Pharmacol. 1991;43: 457-464.

18. Brun PPHL, Fox PLA, Vries MED, Bodde HE. In vitro penetration of some $\beta$ adrenoreceptor blocking drugs through porcine buccal mucosa. Int J Pharm. 1989; 49: 141-145.
19. Caro VD, Giandalia G, Siragusa MG, Paderni C, Campisi G, giannola LI. Evaluation of galantamine transbuccal absorption by reconstituted human oral epithelium and porcine tissue as buccal mucosa models:part I. European journal of Pharmaceutics and Biopharmaceutics. 2008;70:869-873.

20. Cassidy J, Berner B, Chan K, John V, Toon S, Holt B, Rowland M. Human transbuccal absorption of diclofenac sodium from a prototype hydrogel delivery device. Pharm Res. 1993; 10:126- 129. 